\title{
Analysis on the Construction of Green Ecological Architecture System in Wuhan City Circle
}

\author{
Nan Lin \\ School of Civil Engineering and Architecture, Wuhan Polytechnic University, Wuhan, China \\ 430023 \\ 4304835@qq.com
}

\begin{abstract}
Keywords: Wuhan city circle, green architecture, ecological system, evaluation system
Abstract. This paper introduced the necessity of constructing green ecological architecture system in Wuhan city circle, combined with the characteristics of the development of green building in the city, from the construction of regional green ring, hierarchical planning, promotion of green building materials, the application of renewable energy, the establishment of green building evaluation system on several aspects of the analysis and put forward measures for constructing the green ecological system, discusses the supervision and management mechanism of the green building, summary and outlook of the future of Wuhan green building development direction.
\end{abstract}

\section{Introduction}

Wuhan city circle in China's east and west, north and south two major development axis interchange, the middle reaches of the Yangtze River, in the five provinces in central region occupies center position, is an important engine of China's regional economic growth in the future. Construction of urban green ecological system, to deal with the challenges of climate change, explore the urban sustainable development is of great significance. Wuhan is a national architectural applications of renewable energy demonstration city, Wuhan International Expo Center Hall photovoltaic power generation project construction, has been listed for the national renewable energy photovoltaic building demonstration projects. By the end of 2011, Wuhan city circle development green building about 5 million square meters, office buildings and large public buildings energy-saving transformation of 1.32 million square meters, solar energy of renewable energy in building application area of 14.95 million square meters, to promote solar to urban road lighting systems, park and garden lights 0.54 million, all city and county to promote the application of new wall materials and light steel structure new structural system, promote application of bulk cement to 57.3 million tons[1]. Therefore, pushing forward the construction of two oriented society, constructing low-carbon ecological city, the promotion of green building is the necessary way of urban sustainable development.

\section{Development characteristics of green architecture in Wuhan city circle}

The development of green building in Wuhan presents four major characteristics, First is extended from the city center to the new city, new city have been identified in some green building projects; Second is the enthusiasm of enterprises to build green building; Third is star sign projects increased; Forth is green building demonstration zone construction to speed up.

\section{Measures of constructing green ecological system of Wuhan city circle}

Construction of regional green ring. Ecological protection experience of some of the world's big city shows that the surrounding areas in the city to build 20-30 km wide "green ring", to form a regional ecological pattern is good. From the view of Wuhan city circle of regional level, relying on the river, mountains surrounding the area, build the average width of about $20 \mathrm{~km}$ regional ecological ring, the realization of ecological protection, scenic tours, modern urban agriculture, new rural construction, city ecological pattern functions of ecological leisure and so on[2]. Between the groups in the city, the 
construction of multi group combination of natural and artificial ecological green wedge, to the isolation and protective effect on the city circle ecosystem. "Regional green ring" has formed in Wuhan city the development zone and city circle of ecological isolation between several city group, through the six green wedge will be connected to Wuhan city circle and ecological network. Key to protect the city circle in the forest and grassland mainly constituted" Green vein "and" blue vein "zone composed of water body and wetland.

Hierarchical planning. Strengthen urban and rural planning guide, the urban district to be in accordance with the development of green ecological requirements planning, construction, management, organize the preparation of green ecological special planning, including the establishment of the proportion of green building, ecological and environmental protection, public transport, the use of renewable energy, intensive use of land, water resources utilization, waste recycling, and other contents of the index system, organize urban green ecological demonstration, to promote the construction of urban green ecological.

Wuhan city circle has been divided into three levels, which are strictly protected areas, controlled protection and utilization areas, and guide the development and construction zone. The new city in the planning stage, green building will be included in the scope of planning. Focus on promoting the East Lake High Tech Development Zone to build low-carbon ecological demonstration area; construction of Wuhan Wangjiadun business district has become a "national green CBD demonstration zone"; promote green ecological demonstration zone and the national renewable energy application in buildings concentrated demonstration area construction; Qiaokou district riverside ecological community construction become green ecological demonstration zones[3].

Promotion of green building materials. The promotion and application of the new wall materials, focus on the promotion of aerated concrete wall self insulation system, energy efficient windows and doors, movable external sunshade, new energy-saving technology, encourage other construction projects and rural construction projects using the new wall materials. Vigorously promote the bulk cement, ready mixed concrete and mortar, other green building technologies and products.

The application of renewable energy in building. Wuhan International Exhibition Center Hall is one of the domestic top green exhibition hall, the main building with the largest installed capacity of $10 \mathrm{~m}$ tile building integrated solar power system, the project uses the pavilion roof laying polycrystalline silicon solar panels, annual generation capacity of about 9.5 million degrees, 8200 tons of carbon dioxide emissions a year, the exhibition hall and conference center ground source heat pump with universal frequency conventional air conditioning system by combining the hybrid energy system such as (Table 1)[4].

Table 1 Green energy saving technology in Wuhan International Expo Center

\begin{tabular}{|c|c|c|c|}
\hline $\begin{array}{c}\text { Photovoltaic power } \\
\text { generation }\end{array}$ & Compound new energy sources & $\begin{array}{c}\text { Green building demonstration } \\
\text { project }\end{array}$ & Regional low carbon planning \\
\hline Solar power generation & $\begin{array}{c}\text { Ground source heat pump } \\
\text { combined with universal } \\
\text { frequency conversion air } \\
\text { conditioner }\end{array}$ & $\begin{array}{c}\text { Adopt green building } \\
\text { technology 18, energy saving } \\
\text { rate of } 60 \%\end{array}$ & $\begin{array}{c}\text { Planning and control of energy } \\
\text { saving standards for each block }\end{array}$ \\
\hline
\end{tabular}

Wuhan is the civil building energy efficiency evaluation system pilot cities, in the city within the scope of the implementation of the $65 \%$ of building energy efficiency standards, start Wangjiadun green CBD building, become the UK sustainable development of urban planning in China promote "green building" of the city.

Sino French Wuhan ecological city may consider cited the Han River water to cool the building and development of geothermal resources, industrial exhaust gas, waste gas for eco-city winter heating. At the same time, it can also design storage load of energy storage facilities, daytime excess energy stored, for night use. Wuhan city circle has plenty of water, sunlight and farmland, conditions of overall water resources, water purification and recycling ability enhancement. Collection of advanced green building technology, eco-city is expected to advance into the world, leading to a"non carbon energy era ". 
Establish evaluation system of green building. Assessment standard for green building of China officially released in 2006, not only clear the meanings of green architecture, and clear requirements, necessary conditions of green building evaluation is to satisfy all the proposed control standards for residential and public buildings. The index system by the level section, energy saving, water saving, material saving, composition of indoor environment and operation management of six types of indicators. Each indicator includes the control, general items and preferences. Among all the controls must meet, and to meet the general items and preferences of the number is divided into three grades, three-stars is the highest level of the general public buildings. For example, a total of 43, and a total of 14 options, the three-stars level must meet the 36 and 10 respectively, while in the 6 categories of indicators in general terms should respectively meet the corresponding specific. The number are show in Table 2[5].

Table 2 The number of different levels of assessment standard requirements

\begin{tabular}{|c|c|c|c|c|c|c|c|}
\hline \multirow{2}{*}{$\begin{array}{l}\text { Standard } \\
\text { items }\end{array}$} & \multicolumn{6}{|c|}{ General items ( 43 items) } & \multirow[b]{2}{*}{$\begin{array}{l}\text { Optimal } \\
\text { items }\end{array}$} \\
\hline & $\begin{array}{l}\text { Land saving } \\
\text { and outdoor } \\
\text { environment }\end{array}$ & $\begin{array}{c}\text { Energy } \\
\text { conservation } \\
\text { and utilization }\end{array}$ & $\begin{array}{c}\text { Water saving } \\
\text { and utilization }\end{array}$ & $\begin{array}{l}\text { Material saving } \\
\text { and utilization }\end{array}$ & $\begin{array}{c}\text { Interior } \\
\text { environment }\end{array}$ & $\begin{array}{l}\text { operation } \\
\text { management }\end{array}$ & \\
\hline $\begin{array}{l}\text { The total } \\
\text { number } \\
\text { of items }\end{array}$ & 6 & 10 & 6 & 8 & 6 & 7 & 14 \\
\hline$\star$ & 3 & 4 & 3 & 5 & 3 & 4 & \\
\hline$\star \star$ & 4 & 6 & 4 & 6 & 4 & 5 & 6 \\
\hline$\star \star \star$ & 5 & 8 & 5 & 7 & 5 & 6 & 10 \\
\hline
\end{tabular}

\section{Green building supervision and management}

Establish and improve the "project planning design review - construction projects - final acceptance selling products - use" whole process supervision system; from the green building project, planning, design, construction, inspection, operation and management aspects of the specification. Construction department in the preparation of feasibility study report set up green building designed, intends to use the green technology to conduct a feasibility analysis, as far as possible use of renewable energy, and will implement the incremental cost of green building included in the investment estimation; green building project construction bidding should explicitly require bidders to prepare their green construction scheme, supervision department be according to the relevant requirements of green building draw up the supervision plan and to implement; construction administrative department according to file of green building design, green construction scheme and the standard specification for the implementation of supervision and management.

\section{Development direction of green building in Wuhan City}

Establish a comprehensive policy and regulation system to promote green building.Further establish and improve comprehensively promote green building standards system, design, construction, acceptance, operation and management of the whole process of technical standards; establish comprehensively promoting green building supervision and management system, target assessment system, improve the green energy-saving materials certification system; establish comprehensively promote green building technology support system and service system. Preliminary establish sound policies and regulations, improve standards, supervision and management and orderly, reasonable technology system, market main body consciousness development mechanism. 
To build a green building as the core of the industrial chain. The development of green building, to promote green building materials, construction of water-saving products, energy-saving environmental protection industry and renewable energy related industries, and the cultivation of 10 -15 green wall material production, application and development of base, photovoltaic, thermal and geothermal energy, biomass and other as the focus, to promote the new energy industry scale development, cultivation of green architectural design, labeling, consultative 7 consultation service, contract energy management services industry to 2015, initially formed the industrial chain of green building.

Strengthening the construction of green building evaluation capacity.Establishment of technology, product and service support system, cultivate special green building evaluation institutions, responsible for the relevant design consulting, product quality detection, single building third party evaluation and regional planning. Establish green building evaluation system of vocational qualifications, to speed up the training of green building design, construction, evaluation, energy service talent.

\section{Conclusions}

Construction of Wuhan city circle of green ecological system, is conducive to the integration of capital, technology, personnel, information and other factors of production, to the development of the city brought a strong external force, is conducive to the Wuhan innovative mechanism of the development of circular economy, promote the intensive use of resources, forming low input, low consumption, low emissions, recycling of growth mode, to achieve the sustainable development of economy and society.

\section{Acknowledgements}

This work was financially supported by the Science and Technology Research Project of Hubei Provincial Department of Education (Q20141705).

\section{References}

[1] Construction of green building test demonstration zone in Wuhan city circle (2009-2011) implementation of the programme.

[2] Wang Zheqiang. Urban green ring and integrated ecological matrix system[J]. Sichuan Architectural Science Research,2014(3): 309-313

[3] Liang Hui, Xia Baoguo, Liang Bin, Kangfen. Study on the extension and integration pattern of eco tourism resources in Urban Wetland Park -- Based on the data of Wuhan city circle[J]. Forestry economic problems, 2015(4):371-378

[4] Li Bing,Wu Bin,Lin Yaoguang,Tan Jianfeng.Research on Roof Solar Photovoltaic Power Generation System of Wuhan International Expo Center[J]. Construction Technology,2012(3):39-42

[5] Li Cheng, Zhou Xiaobing.Comparison between the green building evaluation standard of China and BREEAM of UK [J]. HV\&AC,2012(10):60-65 